\title{
ANALISIS HUKUM PIDANA ISLAM TENTANG POLIGAMI TANPA IZIN ISTRI
}

\author{
Salamul Huda \\ salamulhuda@yahoo.com 1 RT 6 RW 4 Kanigaran Probolinggo
}

\begin{abstract}
This article analyses sanction of polygamy without proper procedure, namely permission from the wife(s). Polygamy without consent from wife(s) is an offence to the origin of marriage as stipulated in article 279 of the Penal Code. It states that the offender knows the existence of his partner's marriage and the existence of legal obstruction against his action. This offence is punishable with maximum of 5 year imprisonment for those who know the existence of such legal obstruction, and with maximum of 7 year imprisonment if he deliberately conceal it. From the perspective of Islamic criminal law, the offence of polygamy without consent of existing wife(s) is considered ta'zîr because it is a jarimah (offence) which is a breach to individual rights. Punishment of ta'zir depends on the discretion of the regulator.
\end{abstract}

Keywords: Islamic criminal law, polygamy, permission from the wife(s).

Abstrak: Artikel ini membahas tentang analisis hukum pidana Islam terhadap sanksi poligami tanpa izin istri. Poligami tanpa izin istri merupakan bagian dari kejahatan terhadap asal usul pernikahan sebagaimana tertuang dalam Pasal 279 Kitab Undang-Undang Hukum Pidana (KUHP). Dalam Kitab Undang-Undang Hukum Pidana pasal 279 tentang kejahatan asal-usul pernikahan menyebutkan bahwa pelaku yang memenuhi unsur mengadakan perkawinan, mengetahui perkawinan-perkawinannya yang telah ada, mengetahui perkawinan-perkawinan pihak lain, dan adanya penghalang yang sah, diancam pidana penjara 5 tahun bagi yang melakukan pernikahan dengan mengetahui adanya penghalang yang sah dan hukuman penjara 7 tahun bagi yang melakukan pernikahan menyembunyikan penghalang yang sah. Dalam perspektif hukum pidana Islam, melakukan pernikahan tanpa izin istri yang sah merupakan tindak pidana yang mengakibatkan pelakunya mendapatkan hukuman ta'zîr karena merupakan bagian dari jarimah yang menyinggung hak perorangan (individu). Sanksi ta'zîr yang diberikan dalam pelaku tindak pidana tersebut ialah penjara yang ditentukan oleh penguasa.

Kata Kunci: Hukum pidana Islam, poligami, izin istri. 


\section{Pendahuluan}

Kitab Undang-undang Hukum Pidana atau disebut KUHP, yang merupakan peraturan hukum pidana yang saat ini berlaku di Indonesia, selain mengatur perbuatan pidana secara materiil ${ }^{1}$ juga memuat ketentuan ancaman sanksi pidana terhadap tindak pidana perkawinan dalam Pasal 279:

1. Diancam dengan pidana penjara paling lama lima tahun: Ke- 1. Barang siapa mengadakan perkawinan padahal mengetahui bahwa perkawinan atau perkawinan-perkawinannya yang telah ada menjadi penghalang yang sah untuk itu.

Ke-2. Barang siapa mengadakan perkawinan padahal mengetahui bahwa perkawinan atau perkawinan-perkawinan pihak lain menjadi penghalang untuk itu.

2. Jika yang melakukan perbuatan berdasarkan ayat (1) butir 1 menyembunyikan kepada pihak lain bahwa perkawinan yang telah ada menjadi penghalang yang sah untuk itu diancam dengan pidana penjara paling lama tujuh tahun.

3. Pencabutan hak berdasakan Pasal No. 1- 5 dapat dinyatakan. ${ }^{2}$

Tindak pidana perkawinan yang diatur dalam Pasal 279 KUHP termasuk tindak pidana kejahatan terhadap kedudukan perdata. ${ }^{3}$ KUHP Belanda menyebut tindak pidana tersebut dengan dubble huwalijke atau bigami, karena di Belanda dianut prinsip monogami, sehingga tindak pidana semacam itu mengakibatkan adanya 2 (dua) perkawinan.

Di Indonesia, pelaku tindak pidana perkawinan ini pernah dijatuhi sanksi pidana oleh pengadilan sebagaimana putusan Mahkamah Agung Republik Indonesia dalam putusan Nomor 596 K/Pid/2013 yang

\footnotetext{
${ }^{1}$ KUHP yang sekarang diberlakukan bersumber dari hukum kolonial Belanda, yakni Wetboek van Strafrecht voor Nederlandsch Indie. Pengesahannya dilakukan melalui Staatsblad Tahun 1915 Nomor 732 dan mulai berlaku sejak 1 Januari 1918. Setelah kemerdekaan, KUHP tetap diberlakukan berdasarkan Pasal II UUD 1945 disertai penyelarasan dengan pencabutan pasal-pasal yang tidak relevan. Pada tanggal 26 Februari 1946, pemerintah mengeluarkan UU No. 1 Tahun 1946 tentang Peraturan Hukum Pidana yang menjadi dasar hukum perubahan Wetboek van Strafrecht voor Nederlandsch Indie menjadi Wetboek van Strafrecht (WvS), kemudian dikenal dengan Kitab Undang-Undang Hukum Pidana yang saat itu berlaku untuk wilayah Jawa dan Madura. Pada tanggal 20 September 1958, berdasarkan UU No. 7 Tahun 1958, KUHP tersebut berlaku untuk seluruh wilayah Republik Indonesia.

${ }^{2}$ Moeljatno, KUHP: Kitab Undang-Undang Hukum Pidana, (Jakarta: Bumi Aksara, 1996), 101.

${ }^{3}$ Ada 4 (empat) pasal yang berhubungan dengan tindak pidana kejahatan terhadap kedudukan perdata, yaitu Pasal 277, Pasal 278, Pasal 279, dan Pasal 280 KUHP. Terdapat dalam Buku Kedua KUHP tentang Kejahatan (Rechdelictien), secara spesifik diatur dalam Bab XIII tentang Kejahatan terhadap Asal-usul pernikahan.
} 
menyatakan terdakwa atas nama Lenny Rahayu Hartati telah terbukti secara sah dan meyakinkan bersalah melakukan tindak pidana "Melakukan perkawinan, sedangkan perkawinannya yang sudah ada menjadi halangan yang sah baginya untuk kawin lagi" dan menghukum terdakwa ditahan selama 6 bulan. ${ }^{4}$

Tindak pidana perkawinan dalam Peraturan Pemerintah Nomor 9 Tahun 1975 tentang Peraturan Pelaksanaan Undang-undang Nomor 1 Tahun 1974 tentang Perkawinan dan Undang-undang Nomor 22 Tahun 1946 juncto Undang-undang Nomor 32 Tahun 1954 tentang Pencatatan Nikah, Talak, dan Rujuk adalah tindak pidana pelanggaran. Di antara tindak pidana perkawinan adalah poligami tanpa izin istri, karena dalam undang-undang perkawinan dan Kompilasi Hukum Islam, disebutkan bahwa di antara syarat diperbolehkannya poligami adalah adanya izin istri. Dalam KUHP, perkawinan yang diancam sanksi pidana adalah kejahatan melakukan perkawinan sedangkan perkawinannya yang sudah ada menjadi halangan yang sah baginya untuk kawin lagi, pelanggaran terhadap kewajiban untuk mencatatkan perkawinan, dan pelanggaran memutuskan perkawinan tanpa melalui putusan pengadilan.

Mahkamah Agung RI telah memberikan petunjuk berkaitan dengan seorang suami melakukan perkawinan lagi tanpa izin pengadilan, maka dikenakan ketentuan Pasal 45 ayat (1) huruf a juncto Pasal 40 Peraturan Pemerintah Nomor 9 Tahun 1975 tentang Pelaksanaan Undang-undang Nomor 1 Tahun 1974 tentang Perkawinan. Namun, apabila suami pernah mengajukan permohonan izin, tetapi ditolak oleh pengadilan dan suami tersebut tetap melakukan perkawinan, maka dikenakan ancaman Pasal 279 ayat (1) KUHP.5

\footnotetext{
${ }^{4}$ Lihat Mahkamah Agung, Putusan Nomor 596 K/Pid/2013. tanggal 18 November 2013 yang amarnya sebagai berikut: (1) Menyatakan Terdakwa Lenny Rahayu Hartati alias Leny terbukti bersalah melakukan tindak pidana "barang siapa kawin (menikah) sedang ia mengetahui bahwa perkawinannya menjadi halangan yang sah bagi jodohnya itu akan kawin lagi", sebagaimana diatur dan diancam dalam dakwaan kesatu Pasal 279 ayat (1) ke-2 KUHP. (2) Menjatuhkan pidana terhadap Terdakwa berupa pidana penjara selama 6 (enam) bulan penjara dikurangkan dengan masa penahanan yang telah dijalani Terdakwa, dengan perintah Terdakwa ditahan. (3) Menyatakan barang bukti berupa; 1 (satu) lembar kutipan Akta Perkawinan Nomor: 296/T/2008 tanggal 22 September 2008 yang dikeluarkan oleh Kepala Dinas Kependudukan Keluarga Berencana dan Catatan Sipil Labuhan Batu an. Marlon Brando Sibarani dengan Ledya Roselly. Dipergunakan dalam perkara an. Marlon Brando Sibarani; 4. Menetapkan agar Terdakwa membayar biaya perkara sebesar Rp1.000,-(seribu rupiah).

${ }^{5}$ Petunjuk Ketua Mahkamah Agung RI No. MA/Pemb/0156/77, tanggal 25 Februari 1997, tentang Penetapan Undang-undang No. 1 Tahun 1974 dan Peraturan Pemerintah No. 9 Tahun 1975, 10.
} 
Berdasarkan eksplanasi tersebut, perlu dilakukan upaya agar tindak pidana perkawinan tersebut tidak berlanjut yang implikasinya akan semakin meluas. Kebijakan sanksi pidana, terutama untuk tindak pidana perkawinan, selama ini berdasarkan pemikiran bahwa sanksi pidana sebagai ultimum remedium, yaitu usaha terakhir guna memperbaiki tingkah laku manusia. Menurut Van Bemmelen, sanksi hukum pidana merupakan pemberian ancaman penderitaan dengan sengaja dan penerapannya dilakukan jika sanksi-sanksi hukum lain tidak memadai lagi. ${ }^{6}$ Proses tindak pidana perkawinan termasuk jenis delik aduan, artinya delik yang hanya bisa diproses apabila ada pengaduan atau laporan dari orang yang menjadi korban tindak pidana. ${ }^{7}$

Pembaruan kebijakan ancaman sanksi pidana terhadap tindak pidana merupakan hal yang urgen karena sudah tidak sesuai dengan konteks kekinian sehingga tidak kontekstual. Pemerintah sebagai penyelenggara negara mempunyai tanggung jawab untuk memberikan perlindungan, pemajuan, penegakan, dan pemenuhan hak asasi manusia khususnya bidang perkawinan sebagaimana amanat Pasal 28B ayat (1) dan Pasal 28I ayat (4) UUD NRI Tahun 1945. Politik hukum (rechtspolitiek) dalam arti kebijakan hukum terhadap pengaturan ancaman sanksi pidana terhadap tindak pidana perkawinan dalam hukum positif di Indonesia diharapkan akan dapat mengubah perilaku para pelaku perkawinan yang sesuai dengan perkembangan hukum dan masyarakat Indonesia menuju terwujudnya kebijakan atau politik pemidanaan dalam arti keseluruhan yaitu perlindungan masyarakat untuk mencapai kesejahteraan.

Hukum Islam memperbolehkan poligami, namun pembolehan itu diberikan dengan pembatasan dan syarat-syarat yang berat. Pembatasanpembatasan itu antara lain adalah:

1. Poligami diperbolehkan apabila bertujuan untuk mengurus anak yatim dengan adil. Jadi beristri baru itu di sini hanya boleh dengan janda, ibu

\footnotetext{
${ }^{6}$ Andi Zainal Abidin, Azas-azas Hukum Pidana, (Jakarta: Universitas Indonesia, 1987), 16.

${ }^{7}$ Pada dasarnya, dalam suatu perkara pidana, pemrosesan perkara digantungkan pada jenis deliknya. Ada dua jenis delik sehubungan dengan pemrosesan perkara, yaitu delik aduan dan delik biasa. Dalam delik biasa perkara tersebut dapat diproses tanpa adanya persetujuan dari yang dirugikan (korban). Berbeda dengan delik biasa, delik aduan artinya delik yang hanya bisa diproses apabila ada pengaduan atau laporan dari orang yang menjadi korban tindak pidana. Pada delik aduan ini, korban tindak pidana dapat mencabut laporannya kepada pihak yang berwenang apabila di antara mereka telah terjadi suatu perdamaian.
} 
anak yang mana anak yatim yang bersangkutan di bawah pengawasan laki-laki yang akan berpoligami itu. Hal itu diatur dalam al-Qur'an.

2. Jumlah wanita yang dikawini tidak boleh lebih dari empat orang seperti yang terbuat dalam al-Qur'an.

3. Akan sanggup adil diantara istri-istinya itu.

4. Wanita-wanita yang hendak dikawini itu tidak boleh ada hubungan saudara baik sedarah maupun sesusuan. Hal itu disebut dengan jelas dalam al-Qur'an.

Pada awalnya, Islam membolehkan seorang suami atau laki-laki berpoligami dengan alasan:

1. Menopang ekonomi para janda dan anak yatim yan telah kehilangan suami dan ayah mereka pasca perang Uhud.

2. Pemerataan distribusi ekonomi secara adil.

3. Kuatnya kelompok masyarakat tidak memberhalakan sesuatu selain mengabdi kepada Allah (tauhid).

Untuk melakukan perkawinan juga sangat penting mengetahui asal usul agar tidak ada penghalang dalam melakukan perkawinan. Untuk melakukan poligami harus memenuhi persyaratan yang telah ditetapkan Adapun ayat yang membahas tentang mengetahui asal usul adalah ayat 2223 surah an-Nisa' yakni:

"Dan janganlah kamu kawini wanita-wanita yang telah dikawini oleh ayahmu, terkecuali pada masa yang telah lampau. Sesungguhnya perbuatan itu Amat keji dan dibenci Allah dan seburuk-buruk jalan (yang ditempuh). Diharamkan atas kamu (mengawini) ibu-ibumu; anak anakmu yang perempuan; saudara-saudaramu yang perempuan, saudarasaudara bapakmu yang perempuan; saudara-saudara ibumu yang perempuan; anak-anak perempuan dari saudara-saudaramu yang laki-laki; anak-anak perempuan dari saudara-saudaramu yang perempuan; ibuibumu yang menyusui kamu; saudara perempuan sepersusuan; ibu-ibu istrimu (mertua); anak-anak istrimu yang dalam pemeliharaanmu dari istri yang telah kamu campuri, tetapi jika kamu belum campur dengan istrimu itu (dan sudah kamu ceraikan), maka tidak berdosa kamu mengawininya; (dan diharamkan bagimu) istri-istri anak kandungmu (menantu); dan menghimpunkan (dalam perkawinan) dua perempuan yang bersaudara, kecuali yang telah terjadi pada masa lampau; Sesungguhnya Allah Maha Pengampun lagi Maha Penyayang." (Q.S. Al-Nisa’: 22 - 23)

Melihat ayat di atas, ulama Indonesia dan peraturan perundangundangan di Indonesia membolehkan praktik poligami, namun dibatasi 
dengan syarat-syarat tertentu dan dalam kondisi tertentu untuk menghindari niat buruk dalam melakukan perkawinan.

Berdasarkan beberapa hal di atas, maka artikel ini membahas tentang poligami tanpa izin istri dalam perspektif hukum pidana Islam.

\section{Poligami menurut Undang-undang Nomor 1 Tahun 1974}

Kata poligami berasal dari bahasa Yunani. Kata ini merupakan penggalan dari poli atau polus, artinya banyak, dan kata gamein atau gamos artinya kawin atau perkawinan. Jadi perkataan poligami dapat diartikan sebagai suatu perkawinan yang banyak atau suatu perkawinan yang lebih dari seorang. Atau perkawinan poligami merupakan sebuah bentuk perkawinan di mana seorang lelaki mempunyai beberapa orang istri dalam waktu yang sama. Seorang suami mungkin mempunyai dua istri atau lebih pada saat yang sama.

Tunisia adalah satu-satunya negara Muslim yang melarang poligami sekarang ini berdasarkan fatwa dan tafsir Muhammad Abduh, maka Presiden Tunisia Bourguiba pada tahun 1956 untuk mensahkan undangundang (UU) yang melarang poligami. Demikian halnya, Turki saat pemerintahan Musthafa Kemal Ataturk pada tahun 1926 juga melarang poligami. Undang-undang Tunisia yang tegas dan sangat berani melarang poligami tidak diikuti negara lain. Justru sebaliknya, hampir semua negara Muslim di dunia melegalisasi poligami, seperti di Yaman Selatan (1974), Siria (1953), Mesir (1929), Maroko (1958), Pakistan (1961), dan negara Muslim lain. ${ }^{8}$

Poligami di Indonesia juga disahkan sesuai ketentuan Pasal 3 ayat (1) Undang-Undang Nomor 1 Tahun 1974 tentang perkawinan yaitu: Ayat 1 Pada azasnya dalam suatu perkawinan seorang pria hanya boleh mempunyai seorang istri. Seorang wanita hanya boleh mempunyai seorang suami. ' Ketentuan Pasal 3 ayat (2) Undang-Undang Nomor 1 Tahun 1974 tentang perkawinan tersebut membuka kemungkinan seorang suami dapat melakukan poligami apabila dikehendaki oleh istri pertama tentunya dengan izin pengadilan. Ayat (2a) Ppengadilan dapat memberi izin kepada seorang suami untuk beristri lebih dari seorang apabila dikehendaki oleh fihak-fihak yang bersangkutan. Ayat (2b) persetujuan yang dimaksud pada ayat (1) huruf a pasal ini tidak diperlukan bagi

\footnotetext{
${ }^{8}$ Asep Saepudin Jahar Dkk, Hukum keluarga, Pidana \& Bisnis, (Jakarta: Kencana, 2013), 30.

${ }^{9}$ Undang-Undang No 1 Tahun 1974 tentang perkawinan.
} 
seorang suami apabila istri/istri-istrinya tidak mungkin dimintai persetujuannya dan tidak dapat menjadi pihak dalam perjanjian, atau apabila tidak ada kabar dari istrinya selama sekurang-kurangnya 2 (dua) tahun, atau karena sebab-sebab lainnya yang perlu mendapat penilaian dari hakim pengadilan. ${ }^{10}$

Ketentuan di atas merupakan dasar untuk melakukan poligami di Indonesia walaupun menggunakan asas monogami, dibuka juga melakukan poligami dengan syarat yang sudah diatur dalam peraturan perundangan di Indonesia. Adapun kondisi yang dapat dijadikan alasan pengajuan poligami; (a) Sakitnya istri yang tidak bisa disembuhkan, (b) Tidak mampunyai istri memberikan keturunan, dan (c) Tidak mampunyai istri melakukan tugasnya sebagai istri. Sementara syarat-syarat yang harus dipenuhi suami ketika melakukan poligami mencakup; (a) Kemampuan suami untuk berlaku adil, (b) Kemampuan finansial suami, dan (c) Adanya izin istri. Dalam pasal berikutnya, ketika istri tidak ada kabar dalam jangka waktu dua tahun maka tidak perlu melakukan izin pada istri.

\section{Poligami dalam Peraturan Pemerintah Nomor 9 Tahun 1975}

Dalam PP Nomor 9 Tahun 1975 mengatur lebih terperinci tentang Pelaksanaan poligami atas UUP Nomor 1 tahun 1974 tentang Pelaksanaan beristri lebih dari seorang, yaitu:

\section{Pasal 40}

Apabila seorang suami bermaksud untuk beristri lebih dari seorang maka ia wajib mengajukan permohonan secara tertulis kepada Pengadilan.

Pasal 41

Pengadilan kemudian memeriksa mengenai:

1. Ada atau tidaknya alasan yang memungkinkan seorang suami kawin lagi, ialah:

a) bahwa istri tidak dapat menjalankan kewajibannya sebagai istri.

b) bahwa istri mendapat cacat badan atau penyakit yang tidak dapat disembuhkan bahwa istri tidak dapat melahirkan keturunan.

2. Ada atau tidaknya persetujuan dari istri, baik persetujuan lisan maupun tertulis, apabila persetujuan itu merupakan persetujuan lisan, persetujuan itu harus diucapkan didepan sidang pengadilan.

3. ada atau tidak adanya kemampuan suami untuk menjamin keperluan hidup istri-istri dan anak-anak, dengan memperlihatkan:

${ }^{10}$ Ibid. 
a) surat keterangan mengenai penghasilan suami yang ditanda-tangani oleh bendahara tempat bekerja atau.

b) surat keterangan pajak penghasilan atau.

c) surat keterangan lain yang dapat diterima oleh Pengadilan.

4. Ada atau tidak adanya jaminan bahwa suami akan berlaku adil terhadap istri-istri dan anak-anak mereka dengan pernyataan atau janji dari suami yang dibuat dalam bentuk yang ditetapkan untuk itu.

Pasal 42

(1) Dalam melakukan pemeriksaan mengenai hal-hal pada Pasal 40 dan 41, Pengadilan harus memanggil dan mendengar istri yang bersangkutan.

(2) Pemeriksaan Pengadilan untuk itu dilakukan oleh Hakim selambatlambatnya 30 (tiga puluh) hari setelah diterimanya, surat permohonan beserta lampiran-lampirannya.

Pasal 43

Apabila Pengadilan berpendapat bahwa cukup alasan bagi pemohon untuk beristri lebih dari seorang, maka Pengadilan memberikan putusannya yang berupa izin untuk beristri lebih dari seorang.

Pasal 44

Pegawai Pencatat dilarang untuk melakukan pencatatan perkawinan seorang suami yang akan beristri lebih dari seorang sebelum adanya izin Pengadilan seperti yang dimaksud dalam Pasal 43.

\section{Poligami menurut Kompilasi Hukum Islam}

Dalam KHI, ketentuan beristri lebih dari satu orang tertera dalam Bab IX mulai pasal 55 sampai 59. Dalam KHI disebutkan bahwa batasan seorang suami yang hanya boleh menikah sampai empat orang istri saja. Hal itu pun juga dengan persyaratan yang harus dipenuhi. Pasal 55, berisi:

1. Beristri lebih dari satu orang pada waktu bersamaan terbatas hanya sampai empat orang istri.

2. Syarat utama beristri lebih dari seorang, suami harus mampu berlaku adil terhadap istri-istri dan anak-anaknya.

3. Apabila syarat utama yang disebut pada ayat (2) tidak mungkin dipenuhi, suami dilarang beristri lebih dari seorang.

Seorang suami yang hendak beristri lagi harus mendapat izin dari Pengadilan Agama untuk mendapatkan kekuatan hukum yang sah. Hal ini diatur dalam pasal 56, yaitu:

1. Suami yang hendak beristri lebih dari satu orang harus mendapatkan izin dari Pengadila Agama. 
2. Pengajuan permohonan izin dimaksud pada ayat (1) dilakukan menurut tata cara sebagaimana diatur dalam Bab VIII Peraturan No. 9 Tahun 1975.

3. Perkawinan yang dilakukan dengan istri kedua, ketiga atau keempat tanpa izin dari Pengadilan Agama, tidak memunyai kekuatan hukum.

Dalam hal perizinan, seorang suami akan mendapatkan izin dari Pengadilan Agama jika terdapat suatu keadaan yang sesuai dengan ketentuan. Hal ini diatur daam pasal 57, yaitu: Pengadilan Agama hanya memberikan izin kepada seorang suami yang akan beristri lebih dari seorang apabila: (1) Istri tidak dapat menjalankan kewajibannya sebagai istri; (2) Istri mendapat cacad badan atau penyakit yang tidak dapat disembuhkan; (3) Istri tidak dapat melahirkan keturunan.

Sebelum Pengadilan Agama memberikan izinnya, juga harus dipenuhinya suatu persyaratan yang sudah ditentukan. Hal ini diatur daam pasal 58, yaitu:

1. Selain syarat utama yang disebut pasal 55 ayat (2) maka untuk memperoleh izin Pengadilan Agama harus pula dipenuhi syaratsyarat yang ditentukan pada pasal 5 UU No. 1/ 1974, yaitu:

a. Adanya persetujuan istri

b. Adanya kepastian bahwa suami mampu menjamin keperluan hidup istri-istri dan anak-anak mereka.

2. Dengan tidak mengurangi ketentuan pasal 41 huruf $b$ Peraturan Pemerintah No 9/1975, persetujuan istri atau istri-istri dapat diberikan secara tertulis atau dengan lisan, tetapi sekalipun telah ada persetujuan tertulis, persetujuan ini dipertegas dengan persetujuan lisan istri pada siding Pengadilan Agama.

3. Persetujuan dimaksud pada ayat (1) huruf a tidak diperlukan bagi seorang suami apabila istri atau istri-istrinya tidak mungkin dimintai persetujuannya dan tidak dapat menjadi pihak dalam perjanjian atau apabila tidak ada kabar dari istri atau istri-istrinya sekurang-kurangnya 2 tahun atau karena sebab lain yang perlu mendapat penilaian Hakim.

Dalam hal tidak diberikannya izin suami oleh pihak istri diatur dalam pasal 59, yaitu:

Dalam hal istri tidak mau mamberikan peretujuan, dan permohonan izin untuk beristri lebih dari satu orang berdasarkan atas salah satu alasan yang diatur dalam pasal 55 ayat (2) dan 57, Pengadilan Agama dapat menetapkan tentang pemberian izin setelah memeriksa dan mendengar 
istri yang bersangkutan di persidangan Pengadilan Agama, dan terhadap penetapan ini istri atau suami dapat mengajukan banding atau kasasi.

\section{Hukum Acara Poligami}

Permohonan izin beristri lebih dari seorang (poligami) diatur dalam pasal 3, 4 dan 5 UU Nomor 1 tahun 1974, pasal 40 - 44 PP Nomor 9 tahun 1975, pasal 55-59 Kompilasi hukum Islam.

Tata cara permohonan izin poligami diatur sebagai berikut; ${ }^{11}$

A. Poligami harus ada izin dari Pengadilan Agama.

Seorang suami yang hendak beristri lebih dari seorang (poligami) harus mendapat izin lebih dahulu dari Pengadilan Agama (Pasal 56 ayat (1) KHI).

B. Kewenangan Relatif Pengadilan Agama.

Permohonan izin untuk beristri lebih dari seorang diajukan kepada Pengadilan Agama di tempat tinggalnya (pasal 4 ayat (1)UU No.1/1974).

C. Surat Permohonan.

a. Surat permohonan izin beristri lebih dari seorang harus memuat:

i. Nama, umur, dan tempat kediaman Pemohon, yaitu suami dan termohon, yaitu yaitu istri/istri-istri;

ii. Alasan-alasan untuk beristri lebih dari seorang;

iii. Petitum.

b. Permohonan izin Poligami merupakan perkara contentius, karena harus ada (diperlukan) persetujuan istri. Karena itu, perkara ini diproses di Kepanitraan Gugatan dan didaftarkan dalam Register induk Perkara Gugatan.

D. Pemanggilan pihak-pihak.

a. Pengadilan Agama harus memanggil dan mendengar pihak suami dan istri ke persidangan.

b. Pemanggilan dilakukan menurut tatacara pemanggilan yang diatur dalam hukum acara perdata biasa yang diatur dalam pasal 390 HIR dan pasal-pasal yang berkaitan.

E. Pemeriksaan.

a. Pemeriksaan permohonan izin poligami dilakukan oleh Majelis Hakim selambat-lambatnya 30 hari setelah diterimanya surat

\footnotetext{
${ }^{11}$ Arta Mukti, Praktek Perkara Perdata Pada Pengadilan Agama, (Yogyakarta: Pustaka Pelajar, 2007), 241.
} 
permohonan beserta lampiran-lampirannya (pasal 42 ayat (2) PP No. 9/1975).

b. Pada dasarnya, pemeriksaan dilakukan dalam sidang terbuka untuk umum, kecuali apabila karena alasan-alasan tertentu menurut pertimbangan hakim yang dicatat dalam Berita Acara Persidangan, Pemeriksaan dapat dilakukan dalam sidang tertutup (pasal 17 ayat (1) UU No. 14/1970).

F. Upaya damai.

a. Pada sidang pertama pemeriksaan izin poligami, Hakim berusaha mendamaikan (pasal 30 ayat (1) HIR).

b. Jika mencapai perdamaian, perkara dicabut kembali oleh pemohon. $^{12}$

G. Pembuktian.

a. Pengadilan agama kemudian memeriksa mengenai:

i. Ada atau tidaknya alasan yang memungkinkan seorang suami kawin lagi, sebagai syarat alternatif yaitu;

(1) Bahwa istri tidak dapat menjalankan kewajibannya sebagai istri.

(2) Bahwa istri mendapat cacat badan atau penyakit yang tidak dapat disembuhkan

(3) Bahwa istri tidak dapat melahirkan keturunan.

ii. Ada atau tidak adanya persetujuan dari istri , baik persetujuan lisan maupun tertulis, yang harus dinyatakan di depan sidang.

iii. Ada atau tidak adanya kemampuan suami untuk menjamin keperluan hidup istri-istri dan anak-anak dengan memperlihatkan:

(1)Surat keterangan mengenai penghasilan suami yang di tanda tangani oleh bendahara tempat bekerja, atau

(2)Surat keterangan pajak penghasilan; atau

(3)Surat keterangan lain yang dapat diterima oleh pengadilan.

iv. Ada atau tidak adanya jaminan bahwa suami akan berlaku adil terhadap istri-istri dan anak-anak mereka dengan pernyataan atau janji dari suami yang dibuat dalam bentuk yang ditetapkan untuk itu.

${ }^{12}$ Ibid., 242. 
2. Sekalipun sudah ada persetujuan tertulis dari istri persetujuan ini harus dipertegaskan dengan persetujuan lisan di depan sidang, kecuali dalam hal istri telah dipanggil dengan patut dan resmi tetapi tidak hadir dalam sidang dan tidak pula menyuruh orang lain sebagai wakilnya.

3. Persetujuan dari istri tidak diperlukan lagi dalam hal:

a.Istri/istri-istrinya tidak mungkin dimintai persetujuan dan tidak mungkin menjadi pihak dalam perjanjian;atau

b.Tidak ada kabar dari istrinya selama sekurang-kurangnya 2 tahun;atau

c.Karena sebab-sebab lainnya yang perlu mendapat penilaian dari Hakim Pengadilan Agama.

H. Putusan

a. Apabila Pengadilan Agama berpendapat bahwa cukup alasan bagi pemohon untuk beristri lebih dari seseorang, maka Pengadilan Agama memberikan putusannya yang berupa izin untuk beristri lebih dari seorang.

b. Terhadap putusan ini, baik istri maupun suami dapat mengajukan banding atau kasasi. ${ }^{13}$

I. Biaya perkara

Biaya dalam perkara ini dibebankan kepada pemohon (pasal 89 ayat

(1) UU No.7/1989)

J. Pelaksanaan poligami

Pegawai pencatatan nikah dilarang untuk melakukan pencatatan perkawinan seorang suami yang akan beristri lebih dari seorang sebelum ada izin dari Pengadilan Agama yang telah mempunyai ketetapan hukum tetap.

\section{Tindak Kejahatan Perkawinan}

1. Pasal 279 Ayat 1.

Pada dasarnya, KUHP tidak terlepas dengan aturan aturan yang lain perkawinan yang dilaksanakan sesuai dengan tata cara dan hukum masingmasing agamanya adalah sah. Demikian ditegaskan dalam Pasal 2 ayat (1) Undang-Undang No. 1 Tahun 1974 tentang Perkawinan (UU Perkawinan). Ini berarti walaupun pernikahan pria dan wanita tersebut hanya dengan sesuai dengan agamanya, pernikahan tersebut tetap sah. Akan tetapi, perlu diperhatikan juga bahwa dalam Pasal 2 ayat (2) UU

${ }^{13}$ Ibid., 243. 
Perkawinan ditegaskan bahwa tiap-tiap perkawinan dicatat menurut peraturan perundang-undangan yang berlaku.

Dalam KUHP BAB XII Kejahatan Asal Usul Pernikahan dapat dicermati Pasal 279:

1. Diancam dengan pidana penjara paling lama lima tahun:

Ke- 1. Barang siapa mengadakan perkawinan padahal mengetahui bahwa perkawinan atau perkawinan-perkawinannya yang telah ada menjadi penghalang yang sah untuk itu.

Ke-2. Barang siapa mengadakan perkawinan padahal mengetahui bahwa perkawinan atau perkawinan-perkawinan pihak lain menjadi penghalang untuk itu.

2. Jika yang melakukan perbuatan berdasarkan ayat (1) butir 1 menyembunyikan kepada pihak lain bahwa perkawinan yang telah ada menjadi penghalang yang sah untuk itu diancam dengan pidana penjara paling lama tujuh tahun.

3. Pencabutan hak berdasakan Pasal No. 1- 5 dapat dinyatakan. ${ }^{14}$

Unsur-unsur yang terdapat di dalam pasal 279 ayat (1) KUHP yaitu:

1. Unsur Subyektif yaitu "barang siapa". Barangsiapa ini menyebutkan orang sebagai subyek hukum yanng dapat dimintai pertanggungjawaban di depan hukum. Unsur "barangsiapa" harus memenuhi kecakapan hukum baik secara hukum pidana maupun secara perdata.

2. Unsur Obyektif yaitu;

a. Mengadakan perkawinan. Unsur ini menyebutkan seorang suami yang menikah lagi dengan wanita lain yang perkawinannya dipandang sah menurut hukum masing-masing agama dan kepercayaannya itu sebagaimana maksud Pasal 2 ayat (1) UUP).

b. Mengetahui perkawinan-perkawinannya yang telah ada. Unsur ini menyebutkan seorang suami yang melakukan perbuatan sebagaimana disebutkan pada hurup (a), tapi ia secara sadar mengetahui bahwa ia sedang dalam ikatan perkawinan sebagaimana maksud Pasal 2 ayat (2) UUP.

c. Mengetahui perkawinan-perkawinan pihak lain. Unsur ini menyebutkan calon mempelai pasangannya mengetahui bahwa calon pasangannya masih dalam ikatan perkawinan yang sah sesuai maksud Pasal 2 ayat (2) UUP.

\footnotetext{
${ }^{14}$ Moeljatno, KUHP: Kitab Undang-Undang Hukum Pidana, 101.
} 
d. Adanya penghalang yang sah. Unsur ini menyebutkan bahwa kedua calon mempelai memang sudah mengetahui bahwa perkawinan yang akan mereka langsungkan memiliki halangan yang sah, karena calon suaminya masih dalam ikatan perkawinan yang sah.

Unsur utama dalam pasal 279 ayat (1) ialah:

1. Perkawinan-perkawinan yang menjadi penghalang.

Dalam poin ini membahas pasal 279 ayat 1 butir Ke-1 KUHP tentang kejahatan asal usul pernikahan;

1. Diancam dengan pidana penjara paling lama lima tahun:

Ke- 1. Barang siapa mengadakan perkawinan padahal mengetahui bahwa perkawinan atau perkawinan-perkawinannya yang telah ada menjadi penghalang yang sah untuk itu. ${ }^{15}$

Penjelasan pasal di atas menerangkan dikenakan pasal tersebut ketika sesorang melakukan perkawinan dengan sengaja mengetahui ada penghalang dalam melakukan perkawinan. Dari sini dapat dipahami pasal ini lebih membahas terkait pelaksanaan perkawinan yang tidak sesuai dengan UU No 1/1974 tentang Perkawinan.

Walaupun dalam hukum Islam diperbolehkan poligami tetapi pelaksanaanya harus sesuai dengan Undang Undang tersebut. Ketika tidak sesuai maka akan menjadi penghalang yang sah sehingga bisa dikenakan pasal dan ayat tersebut.

2. Perkawinan yang diadakan.

Ketika unsur perkawinan yang dimaksud dalam pasal 279 ayat 1 butir Ke- 2 maka dikenakan sanksi pidana yang isi ayat tersebut;

$\mathrm{Ke}-2$. Barang siapa mengadakan perkawinan padahal mengetahui bahwa perkawinan atau perkawinan-perkawinan pihak lain menjadi penghalang untuk itu. ${ }^{16}$

Dari poin ini yang dimaksud ialah perkawinan yang diadakan yang sah sesuai dengan UU Nomor 1 tahun 1974 tentang Perkawinan jadi pasal ini bisa menjerat seorang ketika melakukan perkawinan yang sah dan ada status perkawinan sah yang lain yang menjadi penghalang untuk melakukan perkawinan. Tidak termasuk dalam ayat ini menjadi penghalang ketika pernikahan yang pertama tidak sesuai dengan undangundang yang berlaku karena perkawinan yang sah yang sesuai dengan undang-undang.

\footnotetext{
${ }^{15} \mathrm{lbid} ., 101$

${ }^{16} \mathrm{lbid}$.
} 
Melihat pasal pada ayat 1 menjelaskan tentang tindak pidana yang dilakukan dengan sengaja melakukan perkawinan yang kedua. Pada pasal tersebut dimaksudkan tidak memberitahukan perkawinan yang kedua pada perkawinan yang pertama yang sah. Dalam ayat pertama mendapatkan ancaman penjara maksimal 5 tahun. Coba bandingkan Pasal 279 ayat (2), maka hukuman yang dijatuhkan lebih berat.

\section{Pasal 279 ayat 2 .}

Pasal 279 ayat 2 pasangan yang telah menikah tidak memberitahukan statusnya, artinya terdapat kebohongan terhadap pasangan dalam perkawinan kedua. Dalam ayat tersebut mempunyai maksud melakukan kebohongan terhadap perkawinan keduanya dengan menyembunyikan status penghalang yang sah terhadap orang lain. Unsurunsur yang terdapat di dalam pasal 279 ayat (2) KUHP yaitu:

1. Unsur Subyektif yaitu "barang siapa". Barangsiapa ini menyebutkan orang sebagai subyek hukum yanng dapat dimintai pertanggungjawaban di depan hukum. Unsur "barangsiapa" harus memenuhi kecakapan hukum baik secara hukum pidana maupun secara perdata.

2. Unsur Obyektif yaitu;

a. Mengadakan perkawinan.Unsur ini menyebutkan seorang suami yang menikah lagi dengan wanita lain yang perkawinannya dipandang sah menurut hukum masingmasing agama dan kepercayaannya itu sebagaimana maksud Pasal 2 ayat (1) UUP).

b. Mengetahui perkawinan-perkawinannya yang telah ada. Unsur ini menyebutkan seorang suami yang melakukan perbuatan sebagaimana disebutkan pada hurup (a), tapi ia secara sadar menyembunyikan bahwa ia sedang dalam ikatan perkawinan sebagaimana maksud Pasal 2 ayat (2) UUP.

c. Adanya penghalang yang sah. Unsur ini menyebutkan bahwa kedua calon mempelai memang sudah mengetahui bahwa perkawinan yang akan mereka langsungkan memiliki halangan yang sah, karena calon suaminya masih dalam ikatan perkawinan yang sah.

Seseorang bisa dikenakan sanksi pidana pidana dengan pasal ini ketika terdapat unsur yang ada dalam pasal tersebut. Beberapa unsur utama seorang dikenakan pasal 279 ayat 2; 


\section{Permasalahan prosedur}

Penekanan pada unsur ini dibahas di ayat dua yang ancaman penjaranya lebih tinggi yaitu tujuh tahun. Karena dalam ayat ini terdapat masalah prosedural dan adminitratif. Ayatnya yang berbunyi;

Jika yang melakukan perbuatan berdasarkan ayat (1) butir 1 menyembunyikan kepada pihak lain bahwa perkawinan yang telah ada menjadi penghalang yang sah untuk itu diancam dengan pidana penjara paling lama tujuh tahun. ${ }^{17}$

Dalam ayat ini ada unsur kesengajaan dalam melakukan tindak pidana perkawinan. Maksud pasal tersebut sama dengan ayat 1 butir ke-1 tetapi penekanan di sini perkawinan yang telah ada disembunyikan. Dalam pelaksanaan poligami bisa dilaksanakan ketika mendapatkan izin dari pengadilan. Maka saat pelaksanaan perkawinan ada penghalang yang sah tapi disembunyikan maka bisa diancam dengan penjara tujuh tahun. Dalam ayat satu melakukan perkawinan yang sah dan mengetahui adanya penghalang dari perkawinan tersebut. Beda dengan ayat ini yang lebih mempermasalahkan terkait menyembunyikan status penghalang yang sah dan melakukan perkawinan yang kedua.

Tujuan dari pasal ini yang pertama melarang seseorang menyembunyikan status perkawinanya ketika melakukan perkawinan yang kedua padahal perkawinan sebelumnya akan merintanginya. Karena pluralisme hukum yang ada di Indonesia mengatisipasi terjadinya perkawinan yang dilakukanya tidak sesuai dengan undang-undang yang berlaku. Kemudian, kedua aturan itu awalnya ditujukan untuk mencegah hubungan seksual yang tidak diinginkan. Meskipun, seperti diketahui juga, dalam praktiknya ada juga pihak-pihak yang terus membela bahwa dengan adanya perkawinan, dianggap telah menghapuskan sifat jahat perzinahan. Padahal, kalau dilihat efeknya pada pasangan sebelumnya yang tidak mengetahui perkawinan tersebut, tentu dampaknya sama saja, yaitu terjadi perselingkuhan, dalam arti perbuatan tak diinginkan terhadap pasangan sebelumnya yang dilakukan secara diam-diam/dengan kebohongan.

\section{Poligami sebagai Tindak Pidana Perkawinan}

Ketika berbicara soal pidana di Indonesia tidak terlepas dengan Kitab Undang-Undang Hukum Pidana (KUHP). Kitab tersebut

\footnotetext{
${ }^{17}$ Kitab Undang-undang Hukum Pidana, BAB XIII tentang Kejahatan Asal-usul Pernikahan.
} 
merupakan warisan dari Belanda selama tidak ada undang undang baru yang terbaru mengatur terkait pidana maka keberlakuan aturan pidana menggunakan KUHP selama tidak bertentangan dengan UUD 1945. KUHP masih digunakan untuk mengisi kekosongan hukum di Indonesia sampai sekarang ada beberapa pasal yang sudah tidak berlaku di KUHP.

Pada era Presiden Soekarno sebagai Presiden pertama di Indonesia mengeluarkan peraturan Presiden Nomor 2 Tahun 1845 tanggal 10 Oktober 1945 yang ter diri dari dua pasal yakni;

Pasal 1

"Segala badan-badan negara dan peraturan-peraturan yang ada sampai berdirinya Republik Indonesia pada tanggal 17 Agustus 1945, sebelum diadakan yang baru menurut Undang-Undang, masih tetap berlaku asal saja tidak bertentangan dengan Undang-Undang Dasar tersebut"

Pasal 2

"Peraturan ini mulai berlaku tanggal 17 Agustus 1945"

Sebagai dasar yuridis pemberlakuan hukum pidana warisan kolonial sebagai hukum pidana positif di Indonesia, keluarlah Undang-undang Nomor 1 Tahun 1946 tentang Peraturan Hukum Pidana.

Dijelaskan dalam Undang-undang Nomor 1 tahun 1974 pasal 2 pekawinan yang sah dilakukan sesuai dengan ketentuan agama dan kepercayaan masingmasing. Selanjutnya, dalam pasal tersebut ditegaskan bahwasanya perkawinan harus dicatatkan menurut undang-undang yang berlaku. Dalam hal ini pelaksanaan dari Undang-undang Nomor 1 tahun/1974 ialah Peraturan Pemerintah Nomor 9 Tahun 1975.

Asas yang berlaku menurut Undang-undang No 1 tahun 1974 monogami yaitu pria boleh menikah dengan satu istri dan sebaliknya. Dalam ayat selanjutnya penegasan pelaksanaan poligami bisa dilakukan yang diajukan di pengadilan dengan syarat mendapatkan izin dari istri dengan alasan-alasan yang kuat. Ini merupakan peraturan dalam melaksanakan poligami KUHP memberikan sanksi ancaman pidana penjara ketika tidak sesuai dengan aturan perdata tersebut.

Kitab Undang-Undang Hukum Pidana terdiri dari tiga buku; pertama tentang aturan hukum, kedua tentang kejahatan, dan ketiga tentang pelanggaran. Dalam buku pertama pasal 1 dijelaskan bahwa sebuah perbuatan tidak dapat dipidana, kecuali' berdasarkan ketentuan perundang-undangan pidana yang berlaku ini yang dikenal dengan asas legalitas. 
Pasal 279 Kitab Undang-undang Hukum Pidana (KUHP). Ketentuan Pasal 279 Kitab Undangudang Hukum Pidana memandang perbuatan poligami ilegal yang telah ditetapkan oleh Undang-undang sebagai perbuatan pidana kategori kejahatan ringan (rechtsdeliktern) yang dapat diancam sanksi pidana. Pasal 279 ayat (1) KUHP menjelaskan sebagai berikut, diancam dengan pidana penjara paling lama lima tahun:

1. Barang siapa mengadakan perkawinan padahal mengetahui bahwa perkawinan atau perkawinan-perkawinannya yang telah ada menjadi penghalang yang sah untuk itu.

2. Barang siapa mengadakan perkawinan padahal mengetahui bahwa perkawinan atau perkawinan-perkawinan pihak lain menjadi penghalang untuk itu.

Melihat unsur-unsur yang terkandung di dalam Pasal 279 ayat (1) KUHP, mendapat hukuman ancaman lima tahun ketika mengadakan perkawinan mengetahui adanya penghalang yang sah.

Pasal 279 ayat (2) menjelaskan sebagai berikut;

Jika yang melakukan perbuatan berdasarkan ayat (1) butir 1 menyembunyikan kepada pihak lain bahwa perkawinan yang telah ada menjadi penghalang yang sah untuk itu diancam dengan pidana penjara paling lama tujuh tahun.

Dalam ayat (2) ini mendapat ancaman maksimal penjara 7 tahun ketika pelaku melakukan perkawinan dan menyembunyikan penghalang yang sah. Sebelum kita menganalisis secara dalam pasal tersebut alangkah baiknya kita mengetahui dulu apa yang dimaksud dengan perstiwa pidana. Peristiwa pidana yaitu setiap perbuatan yang melanggar peraturan hukum pidana yang akan diancam dengan hukuman tertentu dengan Undangundang di mana seseorang itu dapat dipersalahkan dan perbuatannya dapat dipertanggungjawabkan.

Dengan demikian, unsur-unsur yang harus terpenuhi untuk menilai suatu tindak pidana yaitu: Pertama, adanya perbuatan, termasuk tidak berbuat. Dalam pasal ini yang bisa dijeratkan terhadap seseorang ketika melakukan perbuatan perkawinan. Dalam perbuatan pidana perkawinan ini terjadi ketika pelaksanaan perkawinan kedua terdapat penghalang yang sah. Perbuatan tersebut harus mendapatkan izin dari pengadilan ketika syarat tersebut dipenuhi sah melakukan poligami.

Kedua, perbuatan tersebut melanggar ketentuan pidana. Melawan hukum secara objektif yang dimaksud ketika melakukan perkawinan yang 
sebenarnya ada penghalang tetapi tetap melakukan perkawinan tersebut. Unsur ini melawan hukum secara objektif ini terlihat jelas sesuai dengan teks pada pasal 279 KUHP.

Ketiga, perbuatan tersebut diancam hukuman pidana. Dalam pasal 279 terdapat dua ancaman apabila pelaku melakukan tindak pidana tersebut; Pertama, diancam dengan pidana lima tahun ketika seseorang melakukan pernikahan mengetahui adanya penghalang yang sah. Kedua, diancam tujuh tahun ketika seseorang melakukan pernikahan dengan menyembunyikan penghalang yang sah.

Keempat, dilakukan orang tertentu dengan bersalah. Keadaan pelaku dalam tindak pidana perkawinan ini ketika suami istri melakukan perkawinan kedua dan ada penghalang yang sah. Istri pertama melaporkan ke pengadilan dalam pernikahan kedua suami menggunakan status palsu, maka unsur keadaan yang menyertainya menyembunyikan status perkawinan yang pertama. Kasus ini dapat dijeratkan kepada seseorang disaat ada yang melaporkan.

Kelima, orang tersebut dapat dipertanggungjawabkan. Pelaku dapat dipertanggungjawabkan melihat UU perkawinan seseorang bisa melakukan poligami dengan syarat-syarat tertentu. Salah satu syarat mendapatkan izin dari istri melalui pengadilan agama. Ketika seseorang melakukan tindak pidana pernikahan ini maka harus memiliki bukti perkawinan yang sah.

Pada Bab XII tentang kejahatan asal-usul perkawinan pasal 279 ini lebih fokus membahas tentang tindak pidana perkawinan. Dikatakan tindak pidana perkawinan karena dalam pasal ini terdapat rumusan perbuatan pidana dalam perkawinan. Kalau sebelumnya membahas tentang unsur perbuatan pidana. Sekarang dapat dirumuskan dalam pasal ini terdapat rumusan dalam pasal 279 di antara rumusannya adalah:

1. Merugikan orang lain. Dikatakan merugikan orang lain karena dalam pasal ini memiliki korban yaitu istri/suami yang sah sesuai dengan undang-undang berlaku. Pelaku melakukan perkawinan dengan sengaja dengan seseorang melakukan perkawinan dan mengetahui ada penghalang yang sah.

2. Melakukan perkawinan dengan sengaja untuk melawan hukum. Karena sudah diatur dalam pasal 279 ayat 1 ketika mengadakan perkawinan yang kedua dengan sengaja mengetahui ada penghalang 
yang sah maka keduanya diancam dengan pidana penjara lima tahun. Perkawinan ini sengaja melawan hukum secara objektif.

3. Melakukan perkawinan dengan menyembunyikan status penghalang yang sah. Dalam pasal 279 ayat kedua ini lebih berat ancaman pidana dengan ancaman penjara tujuh tahun. Ayat kedua ini memiliki unsur menyembunyikan status yang menjadi penghalang yang sah. Konteks ini memiliki unsur membohongi untuk melakukan perkawinan tanpa diketahui pihak lain kalau ada penghalang yang sah.

Penjelasan di atas merupakan bentuk ketentuan hukum Kitab Undang- Undang Hukum Pidana. Maka ketentuan penetapan ancaman terhadap tindak pidana perkawinan juga sering disebut pidana poligami illegal. Dalam hukum di Indonesia sudah diatur tentang perkawinan dalam UU No1 /1974 dan Peraturan Pemerintah Nomor 9 Tahun 1975 untuk melakukan poligami. Apabila terdapat unsur-unsur yang memenuhi kejahatan dalam melakukan perkawinan yang memiliki penghalang yang sah diatur dalam KUHP pasal 279 tentang Asaal-usul Pernikahan.

\section{Analisis Hukum Pidana Islam}

Kejahatan terhadap pernikahan diatur dalam pasal 279 KUHP tentang kejahatan asal-usul pernikahan. Dalam pasal tersebut dijelaskan bahwa seseorang dapat dipenjara ketika melakukan perkawinan padahal ia mengetahui atau menyembunyikan penghalang yang sah. Dikatakan kejahatan karena melakukan perkawinan dengan unsur kejahatan.

Dalam Islam, ketika seseorang melakukan kejahatan maka harus ada pertanggungjawaban pidana. Islam membagi dua dalam mengatur hukuman pidana Islam, pertama jarîmah hudûd yaitu hukuman yang diberikan terhadap pelaku pidana sesuai dengan al-Qur'an dan hadis. Kedua jarîmah ta'zîr yaitu sanksi pidana yang diberlakukan untuk pelaku pidana tidak terdapat dalam al-Qur'an dan hadis serta hukuman ini ditentukan oleh penguasa.

Dalam hal ini, pasal 279 KUHP merupakan tindak pidana perkawinan yang tidak diatur dalam al-Qur'an dan hadis. Maka pasal tersebut termasuk hukuman ta'zîr yang digunakan dalam sanksi pidana yaitu hukuman ta'zîr. Dalam hal ini hukumannya tidak ditentukan oleh syara' dan penentuan hukumnya ditentukan oleh penguasa. Dasar untuk 
melakukan hukuman ta'zîr sudah dijelaskan dalam al-Qur'an dan hadis. Dalam ayat al-Qur'an surah al-Fath ayat 8-9 ${ }^{18}$ :

"Sesungguhnya Kami mengutus kamu sebagai saksi, pembawa berita gembira dan pemberi peringatan. supaya kamu sekalian beriman kepada Allah dan Rasul-Nya, menguatkan (agama)Nya, membesarkan-Nya. Dan bertasbih kepada-Nya di waktu pagi dan petang"

Salah satu hadis yang menjadi dasar pelaksanaan hukuman ta'zîr sebagai berikut;

Hadis Nabi yang diriwayatkan oleh Bahz ibn Hakim, "Dari Bahz ibn Hakim dari ayahnya dari kakeknya, bahwa Nabi saw menahan seseorang karena disangka melakukan kejahatan. (Hadits diriwayatkan oleh Abu Daud, Turmudzi, Nasa'i, dan Baihaqi, serta dishahihkan oleh Hakim)."19

Kata ta'zîr dalam berarti membesarkan, memperhatikan, membantu, dan menguatkan (agama Allah). Sementara M. Nurul Irfan dan Masyarofah mengatakan bahwa ta'zîr adalah pengajaran dan tidak termasuk dalam kelompok had. Ta'zîr ialah pengajaran yang tidak sampai pada ketentuan had syar'i, seperti pengajaran terhadap seseorang yang mencaci-maki (pihak lain) tetapi bukan menuduh (orang lain berbuat zina). Dalam definisi ini terdapat kalimat tidak sampai pada ketentuan had syar'i. Hal ini sesuai dengan pernyataan Al-Fayyumi dalam definisi di atas, yaitu ta'zîr adalah pengajaran dan tidak termasuk dalam kelompok had. Dengan demikian ta'zîr tidak termasuk dalam katagori hukuman hudûd. Namun, bukan berarti tidak lebih keras dari hudûd, bahkan sangat mungkin berupa hukuman mati.

Dari definisi tersebut, jelaslah bahwa takzir adalah suatu istilah untuk hukuman atas jarîmah yang hukumannya belum ditetapkan oleh syara', melainkan diserahkan kepada ulil amri, baik penetapannya maupun pelaksanaannya.

Di kalangan fukaha, jarîmah yang hukumannya belum ditetapkan oleh syara' dinamakan dengan jarîmah ta'zîr. Jadi, istilah ta'zîr bisa digunakan untuk hukuman dan bisa juga untuk jarimah (tindak pidana).

Dalam menentukan hukuman ta'zîr, penguasa hanya menetapkan hukuman secara global saja. Artinya, pembuat undang-undang tidak menetapkan hukuman untuk masing-masing ta'zîr, melainkan hanya menetapkan sekumpulan hukuman, dari yang seringan-ringannya sampai

\footnotetext{
${ }^{18}$ Makhrus Munajat, Hukum Pidana Islam di Indonesia, (Yogyakarta: Teras, 2009), 182.

${ }^{19}$ Al-Nasa'i, "Sunan”, CD. Mausu'ah Hadits al-Syarif, Hadits Nomor 4792.
} 
yang seberat-beratnya. Dengan demikian, ciri khas dari jarîmah ta'zîr itu adalah sebagai berikut: 1 . Hukumannya tidak tertentu dan tidak terbatas. Artinya, hukuman tersebut belum ditentukan oleh syara', ada batas minimal dan ada batas maksimal. 2. Penentuan hukuman tersebut adalah hak penguasa. ${ }^{20}$

Tujuan memberikan sanksi kepada pelaku ta’zîr mengandung aspek kemaslahatan bagi kehidupan masyarakat, yakni:

1. Sebagai preventif, yaitu bahwa sanksi ta'zîr harus memberikan dampak positif bagi orang lain (orang yang tidak dikenai hukuman ta'zîr), sehingga orang lain selain pelaku tidak melakukan perbuatan yang sama.

2. Sebagai represif, yaitu bahwa sanksi ta'zîr harus memberikan dampak positif bagi pelaku sehingga tidak mengulangi perbuatan yang menyebabkan pelaku dikenakan sanksi (jera). Oleh karena itu, sanksi ta'zîr, baik dalam tujuan sanksi preventif dan represif harus sesuai dengan keperluan, tidak lebih dan tidak kurang dengan menerapkan prinsip keadilan.

3. Sebagai kuratif, yaitu sanksi ta'zîr harus mampu membawa perbaikan sikap dan prilaku terhukum dikemudian hari.

4. Sebagai edukatif, yaitu sanksi ta'zîr harus mampu menumbuhkan hasrat pelaku ataupun orang lain untuk mengubah pola hidupnya sehingga pelaku akan menjauhi perbuatan maksiat bukan karena takut hukuman melainkan karena tidak senang terhadap kejahatan. Dalam hal ini pendidikan agama sebagai sarana memperkuat keimanan dan ketakwaannya, sehingga ia menjauhi segala macam maksiat untuk mencari keridhaan Allah swt. ${ }^{21}$

Jarîmah ta'zîr yang dilihat dari hak yang dilanggar, dapat dibagi ke dalam dua bagian, yaitu:

1. Jarimah ta'zîr yang menyinggung hak Allah.

2. Jarimah ta'zîr yang menyinggung hak perorangan (individu). ${ }^{22}$

Tindak pidana perkawinan dalam pasal 279 KUHP ini merupakan jarîmah yang menyinggung hak perorangan (individu) karena unsur yang terdapat ialah merugikan hak perorangan dengan sengaja, sehingga ada

\footnotetext{
${ }^{20}$ M. Nurul Irfan dan Masyarofah, Figh Jinayah, (Jakarta: Amzah, 2013), 137.

${ }^{21}$ A. Djazuli, Figh Jinayah (Upaya Menanggulangi Kejahatan dalam Islam), (Jakarta: PT Grafindo Persada, 2000), 186.

${ }^{22}$ Amir Syarifuddin, Garis-Garis Besar Fiqih, (Jakarta: Kreana Pernada, 2003), 252.
} 
yang dikorbankan oleh pelaku yang melakukan kejahatan sesuai dengan pasal tersebut. Penjeratan pada pasal ini memiliki dampak yang merugikan hak orang lain di antaranya istri yang sah (korban) dan keturunan.

Jarîmah ini berkaitan dengan kemaslahatan individu. Maksud dari berkaitan dengan individu pelaku ketika melakukan kejahatan pasal tersebut akan melakukan penipuan dan pemalsuan. Penipuan yang dimaksud ialah ketidak jujuran pelaku melaksanakan perkawinan kedua dengan menyembunyikan penghalang yang sah terhadap pihak lain. Pemalsuan identitas pasti dilakukan ketika dikaitkan dengan pasal tersebut karena untuk melakukan poligami harus mendapatkan izin istri lewat pengadilan.

Dalam konteks ini Islam sangat menjaga kehormatan wanita karena nabi Muhammad saw tidak pernah merendahkan wanita. Untuk menjaga itu semua, maka tindak pidana ini bisa dikaitkan dengan perbuatan yang perlu mendapatkan sanksi hukum. Karena pada dasarnya ketika seseorang melakukan kejahatan harus mempertanggungjawabkan perbuatannya.

Ketika seseorang melakukan tindak pidana kejahatan perkawinan yang diatur dalam pasal 279 KUHP, maka pelaku mendapatkan sanksi sesuai yang ditetapkan penguasa. Dalam pasal ini ketika pelaku kejahatan perkawinan dikenakan hukuman penjara, sesuai dengan ancaman penjara dalam pasal tersebut. Hal tersebut sesuai dengan konsep ta'zîr dalam hukum pidana Islam.

Dalam pidana Islam, hukuman penjara bukan sebagai hukuman utama. Berbeda dengan hukum positif yang berlaku di Indonesia yang mengutamakan hukuman penjara. Karena dalam Islam hukuman penjara ini merupakan hukuman pilihan dalam Islam ketika tidak diancam hukuman penjara maka dihukum jild (cambuk). Dalam hukum positif, hukuman penjara sebagai hukuman pokok (utama), dalam kejahatan perkawinan, dan ini menjadi persoalan yang sangat serius karena menyangkut tentang hak perorangan.

Hukuman penjara yang dimaksud dalam pasal ini ialah bukan penjara terbatas, karena dibatasi ancaman maksimal untuk dijatuhkannya sanksi. Hukuman penjara terbatas dalam Islam ini memberikan kebebasan pada penguasa dalam memberikan hukuman.

Dalam hukum pidana Islam, untuk mengetahui suatu perbuatan itu dapat dipandang sebagai perbuatan jarîmah dan pelakunya dapat dikenai pertanggungjawaban pidana apabila telah terpenuhi beberapa unsur, yaitu; 
1. Unsur formil (adanya Undang-undang atau nash)

Dalam syariat Islam lebih dikenal dengan nash yaitu al-Qur'an dan hadis. Dalam syariat Islam, dikenal dengan ar-rukn as-syar iy bahwa jarîmah (perbuatan pidana) tidak ada hukumannya sebelum adanya nash.

Dalam hukum positif dikenal dengan Kitab Undang-Undang Hukum pidana (KUHP) dan sering juga dikenal dengan sebutan asas legalitas. Karena dalam hukum pidana Islam menggunakan hukuman ta'zîr. Maka, penetapan hukuman tergantung penguasa dalam negara tersebut. Jadi, dalam hal ini ketentuan hukuman ditentukan di KUHP.

2. Unsur materil (sifat melawan hukum)

Dalam KUHP dalam pasal 279 dinyatakan ketika seseorang dengan sengaja atau menyembunyikan penghalang yang sah untuk melakukan perkawinan maka dikenakan sanksi pidana penjara. Dalam hal ini sangat jelas pasal tersebut mengatur tindak pidana perkawinan. Hukum pidana Islam mengatakan seseorang membentuk jarîmah, baik sengaja maupun tidak sengaja, jika bertentangan dengan aturan yang berlaku. Dalam hukum pidana Islam disebut ar-rukn al-mâddiy.

3. Unsur moril (Pelakunya mukallaf)

Dalam KUHP diatur bahwa seorang anak dan orang gila tidak diberlakukan hukum terhadapnya. Dengan demikian berlakunyan pasal 279 terhadap orang yang dewasa sesuai dengan hukum positif. Dalam syariat Islam disebut ar-rukn al-adabiy. Orang yang melakukan tindak pidana dapat dipersalahkan dan dapat disesalkan, artinya bukan orang gila, anak-anak dan bukan karena dipaksa atau karena pembelaan diri.

Pemberian hukuman ta'zîr sesuai dengan konsep metode sadd azhzharîah merupakan hukum yang awalnya diperbolehkan dan menjadi larangan karena melihat kemudharatan yang terjadi, adapun ada tiga kriteria yang menjadikan suatu perbuatan itu dilarang, yakni:

Pertama, perbuatan yang tadinya boleh dilakukan itu mengandung kerusakan. Dalam al-Qur'an dan hadis, tidak ada hukuman pidana bagi tindak pidana melakukan pernikahan jika mengetahui dan menyembunyikan penghalang yaitu izin dari istri pertama. Perbuatan tersebut diperbolehkan dalam Islam karena mengandung kerusakan ketika tanpa melakukan izin pada istri pertama maka sesuai dengan konsep sadd azh-zharî̀ah.

Kedua, Kemafsadatan lebih kuat dari pada kemaslahatan. Unsur kemafsadatannya lebih kuat ketika pelaku pernikahan di Indonesia tanpa 
izin istri pertama. Bentuk kemafsadatannya ialah akan terjadi penipuan dalam rumah tangga dan menimbulkan kerusakan dalam rumah tangga.

Ketiga, perbuatan yang dibolehkan syara' mengandung lebih banyak unsur kemafsadatan. Diperbolehkan poligami tanpa izin dalam Islam sesuai dengan kondisi masyarakat Arab pada zaman dahulu, melihat konteks di Indonesia masyarakat tabu akan poligami apalagi tidak izin terhadap istri pertama akan menimbulkan kemafsadatannya lebih banyak dalam masyarakat.

\section{Simpulan}

Berdasarkan pemaparan sebelumnya, kesimpulan dari artikel ini adalah ketentuan hukum dalam Kitab Undang-Undang Hukum Pidana pasal 279 tentang kejahatan asal-usul pernikahan bahwa seseorang mendapat hukuman ancaman lima tahun ketika mengadakan perkawinan dengan mengetahui adanya penghalang yang sah. Selain itu, mendapat ancaman maksimal penjara tujuh tahun ketika pelaku melakukan perkawinan dan menyembunyikan penghalang yang sah.

Unsur-unsur yang terdapat dalam pasal tersebut adalah mengadakan perkawinan, mengetahui perkawinan-perkawinannya yang telah ada, mengetahui perkawinan-perkawinan pihak lain, adanya penghalang yang sah. Perspektif hukum pidana Islam, pemberian hukuman lima tahun dan tujuh tahun bagi pelaku tindak pidana kejahatan asal-usul pernikahan sesuai dengan konsep ta'zîr yang berupa hukuman diberikan sepenuhnya terhadap penguasa sesuai dengan konsep sadd azhzharîah yaitu menutup jalan terhadap sesuatu yang diperbolehkan menjadi tidak boleh untuk menghindari kemudharatan.

Dalam hukum pidana Islam, hukuman dalam Pasal tersebut sesuai dengan hukuman ta'zîr yang digunakan dalam sanksi pidana. Dalam hal ini hukumannya tidak ditentukan oleh syara' tetapi penentuan hukumnya ditentukan oleh penguasa. Tindak pidana perkawinan dalam pasal 279 KUHP ini merupakan jarîmah yang menyinggung hak perorangan (individu). Sanksi ta'zîr yang tepat ketika seseorang melakukan tindak pidana kejahatan perkawinan yang diatur dalam pasal 279 KUHP, maka pelaku mendapatkan sanksi sesuai yang ditetapkan penguasa.

\section{Daftar Rujukan}

Djazuli, A. Fiqh Jinayah (Upaya Menanggulangi Kejahatan dalam Islam). Jakarta: PT Grafindo Persada, 2000. 
Syarifuddin, Amir. Garis-Garis Besar Fiqih. Jakarta: Kreana Pernada, 2003.

Abididn, Andi Zainal. Azas-azas Hukum Pidana. Jakarta: Universitas Indonesia, 1987.

Mukti, Arta. Praktek Perkara Perdata pada Pengadilan Agama. Yogyakarta: Pustaka Pelajar, 2007.

Jahar, Asep Saepudin. Hukum keluarga, Pidana \& Bisnis. Jakarta: Kencana, 2013.

Al-Nasa'iy. "Sunan" dalam CD. Mausu'ah Hadits al-Syarif.

Irfan, M. Nurul. dan Masyarofah. Fiqh Jinayah. Jakarta: Amzah, 2013.

Munajat, Makhrus. Hukum Pidana Islam di Indonesia. Yogyakarta: Teras, 2009.

Moeljatno. KUHP: Kitab Undang-Undang Hukum Pidana. Jakarta: Bumi Aksara, 1996.

Undang-Undang No 1 Tahun 1974 tentang perkawinan. 